NBER WORKING PAPER SERIES

\title{
ETHICAL FOUNDATIONS OF FINANCIAL REGULATION
}

Edward J. Kane

Working Paper 6020

\author{
NATIONAL BUREAU OF ECONOMIC RESEARCH \\ 1050 Massachusetts Avenue \\ Cambridge, MA 02138 \\ April 1997
}

The author wishes to thank Robert Eisenbeis, Stephen Kane, Franco Modigliani, James Moser, and Jonas Prager for helpful comments on previous drafts of this paper, which were presented at MIT, the Federal Reserve Bank of Chicago, Koç University in Istanbul, Turkey, the Southwestern Finance Association, the University of Arizona, and The Wharton Financial Institutions Center Conference on Issues in Risk Management. This paper is part of NBER's research program in Corporate Finance. Any opinions expressed are those of the author and not those of the National Bureau of Economic Research.

(C) 1997 by Edward J. Kane. All rights reserved. Short sections of text, not to exceed two paragraphs, may be quoted without explicit permission provided that full credit, including $\mathbb{C}$ notice, is given to the source. 
Ethical Foundations of Financial Regulation

Edward J. Kane

NBER Working Paper No. 6020

April 1997

Corporate Finance

\begin{abstract}
Regulation consists of rulemaking and enforcement. Economic theory offers two complementary rationales for regulating financial institutions. Altruistic public-benefits theories treat rules as governmental instruments for increasing fairness and efficiency across society as a whole. In contrast, agency-cost theory recognizes that incentive conflicts and coordination problems arise in multiparty relationships and that regulation introduces opportunities to impose rules that enhance the welfare of one sector of society at the expense of another.

Each rationale sets different goals and assigns responsibility for choosing and adjusting rules differently. Altruistic theories routinely assign regulation to governmental entities. These theories empower government officials to search for market failures and to correct them. It is taken for granted that society may rely on well-intentioned government officials to use their discretion to choose actions that advance the common good.

Agency-cost theories portray regulation as a mechanism for enhancing the quality of financial services by improving incentives to perform contractual obligations in stressful circumstances. These private-benefits theories count on self-interested parties to spot market failures and to correct them by opening additional markets. In financial services, markets for regulatory services produce outside discipline that controls and coordinates industry behavior. Institutions benefit from regulation that: enhances customer confidence; increases the convenience of customer transactions; or generates cartel profits. Agency-cost theories emphasize the need to reconcile conflicts between the interests of institutions, customers, regulators, and taxpayers.

To overcome nontransparency and disinformation in the performance measurements that government regulators are permitted to transmit to taxpayers, society must strive to allocate regulatory rights, duties, and rewards in ways that reduce agency costs. To achieve accountability, public-service contracts must be supported by information flows that clarify the consequences of the policy choices being made.

Only if we assume a free flow of information may we suppose that, in long-run equilibrium, competition between government and private regulators would simultaneously improve efficiency, limit the size of net regulatory burdens, and break down cartel pricing. In a world with incomplete or asymmetric information, statutory constraints on performance measurement and the exercise of individual regulatory discretion provide a way to limit departures from socially optimal patterns of rulemaking and enforcement.
\end{abstract}

Edward J. Kane

Finance Department

Boston College

Chestnut Hill, MA 02167

and NBER

howes/mf@hermes.bc.edu 


\title{
ETHICAL FOUNDATIONS OF FINANCIAL REGULATION*
}

\author{
Edward J. Kane \\ Boston College
}

Practicing financial regulators frame discretionary rulemaking and enforcement activity as a top-down exercise in promoting stability, fairness and economic efficiency. This public-benefits characterization offers an altruistic theory of why a benevolent government might authorize a politically independent central bank to regulate private financial institutions as it sees fit.

However, economists are trained to distrust benevolence as a motive. They prefer a self-interested rationale for financial regulation, one that recognizes that narrow private benefits can be extracted from cooperation-inducing regulation. Because of private benefits, conflicts of interest may arise between the central bank and taxpayers as well as between politicians and the central bank.

Incentive-conflict theory portrays financial regulators as self-interested agents that compete atomistically to serve multiple principals: society and private sectoral interests whose goals diverge in part from societal goals. This theory looks for low-cost mechanisms by which to reconcile conflict between regulators' private and societal goals. Placing statutory constraints on regulators may let society improve upon discretionary outcomes by limiting the ability of a central bank or other regulatory enterprise to pursue its or its managers' self-interest at the expense of societal goals.

Both theories anticipate society-wide reductions in agency costs from authorizing a trustworthy party to enforce the performance of financial contracts. But only the second theory acknowledges that information asymmetries and free-rider problems make it matter how regulators are paid and how responsibility for rule-making and enforcement by public managers is disciplined ex post.

Any regulator's trustworthiness may be undermined by opportunistic counterparties who are willing to use incentive-based compensation to tempt the regulator to compromise its fiduciary responsibilities. Consequently, rational stakeholders demand appropriate information flows from private regulators and are quick to respond to evidence of unfaithful performance. Individuals that are harmed by an abusive private regulator may

\footnotetext{
* The author is James F. Cleary Professor in Finance. He wishes to thank Robert Eisenbeis, Stephen Kane, Franco Modigliani, James Moser, and Jonas Prager for helpful comments on previous drafts of this paper, which were presented at MIT, the Federal Reserve Bank of Chicago, Koç University in Istanbul, Turkey, the Southwestern Finance Association, the University of Arizona, and The Wharton Financial Institutions Center Conference on Issues in Risk Management.
} 
seek redress as a class through government-operated courts. If successful, plaintiffs may even be awarded punitive damages.

By contrast, government regulatory enterprises resist the disclosure of adverse information and offer few opportunities for taxpayers to enforce their interests in regulatory performance by means of market trading or the courts. Both for society and for private parties, transactions with regulators include implicit costs and benefits that make it hard to document violations of common-law duties and to measure how putative violations affect the distribution of wealth. Moreover, as government servants themselves, prosecutors and judges may be particularly sympathetic to the conflicting pressures under which fellow officials operate. These difficulties raise the costs to taxpayers of enforcing faithfulness in government regulation. High enforcement costs give buyers and sellers of political influence leeway to slant government-produced benefits toward sectoral interests. Taxpayers have difficulty organizing an effective defense of their common interests. A strategy of misrepresenting the motives underlying regulatory decisions and of exchanging benefits in subtle ways protects venal government regulators and regulated institutions ("regulatees") making it hard for disadvantaged taxpayers and customers to prove that any private value was even exchanged.

Although divergent in perspective, both theories entertain the possibility that society may benefit from allowing regulators to compete. Especially in a world that is undergoing rapid technological change, regulatory competition promises to support experimentation that would help even a selfless regulator to identify and eliminate inefficient modes of regulation more quickly. But to assure the social value of regulatory competition, regulators must uncover and disclose a flow of supporting information about their regulatees. To explain how socially good and bad patterns of regulation manage to co-exist for long periods of time, opportunities for regulators to cover up adverse information must be acknowledged. Where misrepresentation and incentive conflicts are not appropriately disciplined by well-informed competition, regulators have an incentive to offer a socially suboptimal menu of regulatory services.

Private-benefits theory stresses the need to resolve incentive conflict in any mix of private and government financial regulation. The first-best solution would be to redesign public-service employment contracts to give regulatory managers a symmetric and transparent stake in the benefits and costs their enterprise generates for taxpayers. The failure of society to develop such contracts implies a welfare loss whose size must be controlled in other ways. In the U.S., taxpayers strive to ameliorate failures in the market for regulatory services by attempting to screen for prior evidence of dishonorable behavior and by enforcing common-law ethical duties on government and private regulators alike. 
But taxpayer information asymmetries and free-rider problems undermine the enforcement system. With incomplete information, it is impossible for society to prevent government regulatory managers from shirking to some degree the regulatory duties they are assigned. If limited to "ethical" controls, taxpayers' relatively greater exposure to "amoral hazard" in government regulation affirms the value of introducing disclosure requirements, market checks, and enforceable limits on the exercise of discretion by government regulatory officials. In particular, schemes that operate private and government regulatory enterprises in tandem promise to improve the quality of information on regulatory performance that taxpayers receive.

Section I summarizes the altruistic theory of government regulation. Section II introduces the ideas of self-interested regulators, public and private regulatory competition, and socially dysfunctional lobbying pressure on government officials. Section III explains how incomplete information about defects in regulatory performance intensifies the incentive conflict a government regulator has to confront. Section IV expands on this theme. It argues that accountability resistance by government managers makes it hard for taxpayers to assure that information and executive compensation will flow in an efficient manner. Section V narrows the focus to explain how a partial privatization of federal deposit insurance would make it harder for authorities both to ignore subtle forms of financial-institution risk-taking and to misrepresent the loss exposures that regulatory policies transmit to taxpayers. Section VI explains how increased transparency in government accounting systems would improve regulatory accountability across the board.

\section{Altruistic Public-Benefits Theories of Financial Regulation}

The traditional "public-benefits" justification for government intervention into private financial activity is rooted in the theoretical welfare economics of A.C. Pigou (1932) and Paul Samuelson (1947). Traditional regulation theory identifies three types of "market failures": conditions under which Adam Smith's market-guiding "invisible hand" of voluntary exchange would fail to direct society's resources to an allocative pattern capable of achieving optimum social welfare. Altruistic government officials can overcome market-crippling obstacles by using taxes, subsidies, laws, and enforcement activities to restructure private incentives.

Efforts to tie public-benefits theory to real-world regulatory behavior operationalize the problem of social welfare maximization. They imbed a vector of overt policy goals, $\mathbf{g}$, into the welfare function $\mathrm{W}[\mathrm{g}]$. Then they specify a policymaking technology, $\mathrm{T}(\ldots)$, that links movements in the goal variables to a designated vector of policy instruments, $\mathbf{x}$. The policymaker is portrayed as wanting to set the elements of $\mathbf{x}$ to maximize $\mathrm{W}[\mathrm{T}(\mathbf{x})]$. 
Altruistic theories of regulation presume that regulators may be paid their transfer wage in noncontingent fashion. They assume that no compensation scheme $\mathrm{S}$ could change a regulator's preference ordering over the potential goal set so that:

$\mathrm{W}(\mathbf{g})=\mathrm{W}(\mathbf{g}, \mathrm{S})$ for all $\mathrm{S}$.

In these circumstances, discretionary government intervention in private markets would aim straightforwardly either at improving incentives for efficient societal resource use or at improving the distribution of claims to resources across society. Altruistic regulation seeks to unwind three adverse conditions that society may encounter:

-- ethically unacceptable inequalities in the observed distribution of opportunities;

-- natural or informational monopolies;

-- welfare linkages in which the activity of one party (A) imposes a cost or benefit on another party (B) for which markets do not penalize or compensate A ("externalities").

Once information asymmetries are introduced, altruistic regulators cannot be presumed to know the true $\mathrm{W}$-function or even the true regulatory technology $\mathrm{T}(\mathbf{x})$. To uncover $\mathrm{T}(\mathrm{x})$, they must spend resources on economic research. To learn about $\mathrm{W}$, they must participate in political processes and analyze opinions expressed by media and academic experts to infer the weights they should assign to different policy goals and instruments at different times. Voters attempt to discipline incumbent officials by periodic elections, while the press operates mechanisms for shaming, punishing, or ousting poorly informed or incompetent officials at other times. Tracking the $\mathrm{W}$ function is particularly hard because the electorate has poor incentives to keep itself informed enough to signal its true preferences among policy strategies (Kahneman, Knetsch, and Thaler, 1986).

\section{$\underline{\text { Standard Justifications for Government Regulation of Deposit Institutions }}$}

Three altruistic justifications for regulating a country's financial industry exist. In each circumstance, theoretical welfare economics authorizes particular regulatory policies only under restrictive conditions.

First, it may be alleged that a particular society's welfare can be served by directing financial institutions to alter the distribution of wealth by offering socially deserving parties free or subsidized access to selected safekeeping, transactional, or credit services. Examples include proposals to mandate free bank accounts for recipients of government welfare or pension payments and government efforts to subsidize mortgage interest rates for the urban or rural poor. But deadweight losses make it hard to engineer advantaged access to financial-institution services in ways that either compensate efficiently for whatever disadvantages face the class of intended beneficiaries or efficiently reward the beneficiaries' extraordinary social "worthiness." 
Second, monopoly power and externalities that might emerge in producing and delivering financial services may be cited as justifications for private and government efforts to supervise and regulate financial-institution pricing and networking behavior. Authorities mention three efficiency goals: to save resources by coordinating institutional activity; to prevent industry monopolization; and to minimize the chance of contagious customer runs.

In practice, authorities emphasize the third goal: to block "systemic" (i.e., economy-wide) damage from a cascade of financial-institution failures. Across coordinated financial systems, officials postulate that damage from an insolvency-revealing run on the liabilities of one institution might be transmitted through a pyramiding of defaults on intraday and overnight credit exposures that clearing institutions accept as part of operative systems for settling net payments. Authorities further postulate that cross-institution defaults might be compounded by irrational runs on sound firms. Clearings losses and customer runs can impose fire-sale losses on institutions if they force the sale of illiquid assets in quick order. It is presumed that the informational "nontransparency" of the risks underlying asset values makes financial instruments hard to sell for fair value without allowing buyers time to double-check the validity of alleged evidence regarding the issuer's creditworthiness. If fire-sale losses were to become extensive, they could harm the economy by destroying the viability of otherwise economically solvent institutions.

However, the danger of irrational runs is easy to overplay. Incentives exist to devise private contract forms and safeguards that mitigate both the frequency of irrational runs and the damage they cause. Benston and Kaufman (1996) and Calomiris and Mason (1994) show that, during financial panics in the U.S., depositors and stock traders have been informed enough to distinguish between solvent and insolvent banks.

Information may be defined as the set of truthful inferences and deductions that a trained analyst could make from public and private data. Information asymmetry exists when one party to a contract has more or different information than one or more other parties. Disinformation consists of deliberately misleading statements about what particular data mean. Disinformative statements are intended to exploit information asymmetries by distorting the inferences and deductions that less-informed parties make.

Both the stabilization and the anti-monopoly goals support efforts to protect society from damages caused by incomplete information. A run is irrational if it is driven by unjustified inferences about the condition of the bank. Customer problems in interpreting information about financial institutions come in large part from institutions' role in mitigating problems that many customers have in communicating convincing information about potential earnings (Diamond, 1984). An individual institution funds customers from 
whom it has previously received reliable inside information about their honesty or favorable future investment prospects. Any liquidity-motivated curtailment in the flow of an individual institution's loans or investments may impose opportunity losses on customers whose prospects are hard for outsiders to value. On this argument, government efforts to avoid fire-sale losses may be interpreted as correcting a failure in private markets for information.

An altruistic regulator would be careful not to reduce incentives for banks and their customers to mitigate the costs of gaps in information on their own. A customer's exposure to funding interruptions is by no means exogenous. A household or business may mitigate its cumulative loss from fluctuations in financial-institution liquidity by establishing multiple points of access to credit.

Because marginal costs of customer-initiated mitigation rise with the expense the firm incurs in communicating its credit quality to alternative suppliers of credit, institutions can earn rewards for undertaking activities that bond their commitments to finance the credit needs of "relationship" customers whose solid prospects are hard to communicate to others. The credibility of a bank's promises is enhanced by access to lines of credit at central-bank discount windows, but every type of institution may bond its funding commitments by taking back-up private steps to protect itself from liquidity pressures.

Every institution may mitigate its customers' exposure to unforecastable liquidity constraints by adopting informative disclosure policies. Informative disclosure means allowing outsiders to monitor an institution's accumulated capital and changes in the riskiness and projected profitability of its future operations. Given the speed with which an institution's portfolio positions can be altered, it is hard for disclosures to be convincing today unless they are backed up by a real-time valuation system and supported by opening the institutions control and information systems to examination by well-incented outside accountants and financial analysts. High fixed costs for individual customers of directly measuring and monitoring bank capital and risk-taking create free-riding problems that make it efficient for the average depositor to rely on trustworthy regulatory agents to monitor and discipline fiduciary institutions on its behalf. These private and governmental supervisory agents must collect, analyze, and certify information and warn small customers and taxpayers about financial-institution weakness in time to protect themselves from losses.

Information asymmetry also creates a need for altruistic government officials to monitor potentially nasty incentive conflicts that might unfold for private monitors and supervisory agents. Access to court proceedings and judicial orders serves the social purpose of enforcing private contracts and overcoming free-rider difficulties that arise, for 
example, in negotiating and enforcing appropriate wind-up rules across stakeholders in failing firms. The less well-developed is a country's legal system, the greater the risk that financial contracts may prove unduly costly for individuals to enforce when defaults occur. Competition Among Government Regulators

Altruistic theories of regulation sometimes introduce the idea of competition among alternative regulatory bodies as a way to generate information and to strengthen incentives for efficient regulation. In practice, bureaucratic structures often allow the regulatory responsibilities of government bureaus to overlap in meaningful ways. In the U.S., competition for jurisdiction over commercial-banking firms ranges over 50 subnational state regulators and three separate federal bureaus: the Federal Reserve, the Comptroller of the Currency, and the Federal Deposit Insurance Corporation. At the same time, these banking regulators compete for administrative authority with foreign banking commissions. Finally, banking regulators compete --albeit less directly-- with regional, national, and foreign regulators of such nonbank financial services firms as insurance companies, securities firms, finance companies, and thrift institutions.

Even in a world of altruistic regulators, a monopolistic governmental regulatory system might be slow to recognize changes in $T(x)$ caused by new regulatee technologies, and uncertainty about $T(x)$ might sustain inefficient patterns of over-regulation (Kane, 1988). Authorizing bureaucratic competition would expand opportunities for altruistic regulators and regulated firms to search out more-efficient patterns for producing, delivering, or financing regulatory benefits. Gains in a bureau's market share and public standing from successful experimentation would reinforce incentives for staff economists and lawyers to test the efficiency of innovative systems of rules and enforcement mechanisms. For example, if banks find it less costly to expand into other informationbased businesses by means of operating subsidiaries [as the Office of the Comptroller of the Currency (OCC) authorized in November 1996] than by holding-company affiliates, the OCC will gain standing relative to the Federal Reserve.

On the other hand, in the realistic case of self-interested regulators and incomplete information, the beneficial force of regulatory competition may prove hard to sustain and competition may create lax enforcement. Unless top government officials are adequately monitored and disciplined by enforceable contracts with the electorate, nonaltruistic government regulators could benefit from dividing up regulatory turf or producing net benefits for their particular clients at the expense of broader indices of social welfare.

\section{Incentive-Conflict Theories of Regulation}


Altruistic theories of regulation locate the initiative for regulation in the public sector. They suppose that altruistic public servants search conscientiously for opportunities to help society to overcome market failures and nobly seize upon the opportunities they find.

An alternative starting point is to recognize that opening additional private markets provides a nongovernmental way to correct market failures (Coase, 1960). Altruistic public-benefits theories of financial regulation neglect opportunities that exist for private parties to organize themselves to provide regulatory discipline efficiently. Private managers ought to be fully aware of ways in which their own net cost of running a financial services firm (FSF) can be reduced if the firm's services are produced in tandem with information and discipline supplied by one or more "external" regulatory servicers. The purpose of voluntarily submitting to regulatory discipline is to inject value-creating cooperative behavior into industry patterns of interfirm competition.

The incentive-conflict theory of why and how financial regulation exists focus on the need for contracts to be fair, efficient, and enforceable. Contracting efficiency looks past market failures to focus on society's need to monitor and police at minimum resource cost the ethical conflicts that inhere in trading and fiduciary relationships. Jensen (1994, p. 45) describes the central proposition of agency theory as follows: "rational selfinterested people involved in cooperative endeavors always have incentives to reduce or control conflicts of interest so as to reduce the losses resulting from them." Like a referee at a sporting event, a reliable outside regulator can improve the fairness, efficiency, and enforceability of financial agreements by offering to mediate transactions in which the interests of financial-institution managers and stockholders, debtholders, and customers diverge.

Private and public fiduciary relationships may be viewed as contracts that delegate obligations to the counterparties. Each obligation establishes a principal-agent relationship. The party for whom the obligation is to be performed becomes a principal and the obliged party becomes the principal's agent. Realistically, every agent has an objective function that differs to some extent from that of its principal. Every agent faces a temptation to evade some of its obligations whenever it can hide self-serving actions or other relevant information from the principal. As long as an agent's actions or their consequences are not transparent to the principal, the agent can promote its self-interest at the principal's expense.

Resource costs are associated with a principal's need to control its agents. It is desirable both for the principal and for society that this control be produced at minimum cost (Jensen and Meckling, 1975). Costs of agency have three components: 
- The principal's cost of monitoring and constraining the agent;

- The costs an agent occurs itself to bond its performance;

- The residual waste and damage that the principal is forced to suffer because of imperfections in the monitoring process or in the design or enforcement of restraints imposed by the agent's contract with the principal.

Agency-cost theories recognize the value of incentive-based compensation and ex post settlement as ways for society to constrain the tradeoffs between public and private benefits that are made by financial-institution managers and by the governmental and private parties that regulate them. Agents are willing to accept tighter control only if they are compensated appropriately for the private benefits that tighter controls take away from them (Fama and Jensen, 1983). From this perspective, bad regulatory outcomes indicate contractual weaknesses in the particular labor markets in which corporate managers and public servants are hired and compensated.

\section{A. A Strictly Private-Benefits Theory of Regulation}

Private regulators seek to maximize a private-value function $\mathrm{V}\left(\mathrm{g}^{\prime}\right)$ that we may assume is increasing in a goal vector whose elements are the individual and joint profits of its regulatees. As before, a regulatory technology of supervision and regulatory discipline $\mathbf{g}^{\prime}=\mathrm{T}(\mathbf{x})$ constrains regulators' effort to maximize $\mathrm{V}[\mathrm{T}(\mathbf{x})]$. Market forces encourage a private regulator to develop employment contracts $S=S_{R}(V)$ that incent its managers and staff to carry out the constrained maximization of $\mathrm{V}[\mathrm{T}(\mathbf{x})]$. In this model, manipulation of the policy instruments $\mathbf{x}$ may be constrained by statutes and by government monitoring. Constraints on private regulators may be conceived as efforts to control the extent to which the private regulators can generate private value at the expense of social value $\mathrm{W}$.

Besides fostering socially undesirable opportunities for cartelization (Stigler, 1971), outside discipline may be sought voluntarily for two salutary reasons: (1) to promote justifiable customer confidence in the soundness of the financial industry and (2) to coordinate firm activities across the industry to increase customer transactional convenience (Kane, 1988). The availability of private value from cartelization, confidence and convenience creates incentives for competing firms to band together to confer authority on reputable private and public entities to examine their books and impose regulatory discipline on them in a cost-efficient fashion.

The atomistic private-benefits theory of financial regulation portrays supervision and regulatory discipline as intermediate goods employed in a team-production technology. These inputs can be obtained from competing private or government suppliers. From a game-theory perspective, the private benefits that regulatory servicers produce come from enforceable multilateral contracts. These contracts coordinate pricing strategy or enhance 
the perceived confidence and convenience that customers attach to the products of the regulated firms. Assuming regulatory competition is strong, the net value created by a private regulatory enterprise would --like Marshallian consumer surplus-- flow to its regulatees.

\section{B. Theory of Self-Interested Government Regulators}

Unlike private regulators, government regulators serve two classes of principal: regulatees and taxpayers. Imbedded in the private value that government regulation creates are taxpayer benefits $\mathrm{B}(\mathbf{x})$ and opportunity costs $\mathrm{c}$ from using taxpayer-owned resources. In a fully informed equilibrium, taxpayers would demand that each government regulator approximate the altruistic maximization of $W[g(\mathbf{x})]$ by charging each regulatee a marketmimicking user fee $u_{i}$ on taxpayers' behalf.

For each firm regulated $(i=1, \ldots, m)$, the user charge $u_{i}$ should equal $c_{i}$, the opportunity cost the firm imposes on government regulatory operations, including resource costs $R_{i}$ and the loss exposure $c\left(L_{i}\right)$ the institution shifts to the safety net by implicitly or explicitly supporting regulatee operations. In principle, a central bank's responsibility for limiting the spread of losses across institutions extends an unmeasured amount of implicit taxpayer support beyond the deposit-institution industry to the securities, futures, insurance, sales-finance, and pension industries as well.

If an informed, but conflicted regulator seeks to serve the industry without imposing a burden on the safety net, its maximization problem may be formulated as follows:

$$
\begin{array}{ll}
\text { Maximize: } & \mathrm{V}(\mathbf{g})+\mathrm{B}(\mathbf{g})-\sum_{i=1}^{m} u_{i} \\
\text { Subject to: } & \mathbf{g}=\mathrm{T}(\mathbf{x}) \\
& \mathbf{g}=\mathrm{T}^{\prime}(\mathrm{x}) \\
& \mathrm{u}_{\mathrm{i}}=\mathrm{c}_{\mathrm{i}}\left[\mathrm{R}_{\mathrm{i}}, \mathrm{L}_{\mathrm{i}}(\mathbf{x})\right] .
\end{array}
$$

Again, the regulator's range of movement in $\mathbf{x}$ may be subjected to statutory limits.

Within government, budget discipline substitutes for profit discipline. For a government enterprise, the counterpart to a private firm's profits is $\mathrm{B}(\mathrm{g})-\sum_{i=1}^{m} c_{i}$. This differs from the projected social value of the net social benefits $\mathbf{g}$ it produces over and above the particular expenses it accounts for in-house. For example, until the late 1980s, the Federal Savings and Loan Insurance Corporation budgeted reductions in Treasury revenue occasioned by granting tax-loss carryforwards to acquirers of failed thrift institutions as reducing its costs of operation. To capture the increment in social "profit" generated by a government enterprise, its performance measure must focus on societywide 
rather than in-house indices of the benefits and costs its activities generate. Otherwise budgets and perquisites are apt to respond to actions that affect the share of aggregate financial-service revenues that pass through a regulator's client firms at the expense of costs that accrue to taxpayers at large. Watchdog institutions in the government, press, and academia could further improve budget discipline by insisting that the implicit reputational and bureaucratic benefits that government officials extract from imperfect taxpayer control be measured and incorporated into a generalized budget statement for each regulatory enterprise.

\section{Agency Perspectives on Lobbying and Influence Peddling}

Agency theory treats fairness and efficiency as potential goals of every regulator. Still, the extent to which these benefits can be realized depends on a regulator's sense of honor and on the way that a regulator's duties are monitored and enforced. Monitoring and enforcement differ between private and governmental entities.

Monopoly power accrues to any established regulatory enterprise, whether it be private or public in nature. Economics predicts that this monopoly power will be wielded by regulatory officials in a self-interested fashion unless the terms of their labor contracts make them appropriately accountable to all stakeholders for the power they exercise.

Lobbying pressure is routinely exerted by regulatees to influence regulatory decisions. Lobbying can have either or both of two main thrusts: (1) to counter the lobbying activity of other sectors; or (2) to promote the sector's own regulatory agenda. A sector's lobbying agenda revolves around increasing (or maintaining) the regulatory burdens on competing sectors and expanding the net benefits that submitting to regulatory discipline generates for itself.

Differences in operative incentive structures make governmental and private regulators apt to respond to industry pressure differently. In particular, the funding structure and greater insolvency potential of a private regulator rewards capital-market participants for uncovering and trading on evidence of bad performance. Typically, this trading softens the prices of the securities that informed traders disgorge and raises questions about the financial condition of the regulator and its clients. Political and personal benefits garnered by government officials who bend to lobbying pressure from powerful sectors (Stigler, 1971; Pelzman, 1976; Becker, 1983) generate fewer and moreambiguous market signals.

Whenever information asymmetries can be established and maintained, regulators and regulatees may connive to allocate the costs and benefits of regulation to other parties, with taxpayers and unsophisticated FSF customers strong candidates for getting the short end of regulatory deals. Poorly monitored opportunities to disguise the costs of regulation 
and to shift them to misinformed third parties can make it profitable for self-interested government regulators to offer their regulatees taxpayer-damaging forms of leniency (e.g., through capital forbearance).

Regulatory competition protects society from over-regulation. To control errors in the other direction, i.e., competition in leniency, watchdog institutions for third parties must be enabled and incented to monitor the opportunity costs government regulators generate. The U.S. savings-and-loan disaster strongly underscores how misreporting taxpayer costs can quiet watchdog institutions and protect the reputations of sitting government officials by deferring public recognition of a problem until someone else's watch.

Figure One models the incentive conflict an informed, but self-interested government regulator faces today. Public-service contracts do little to defend taxpayer interests, while incentive-based side payments offered by regulated parties $S_{R}\left[V\left(g^{\prime}\right)\right]$ tempt regulators to revise their goal function $\mathrm{U}(\ldots)$ to incorporate the private goals $\mathbf{g}$ '. How extensively social goals are sacrificed for private ones depends on ethical values and legal sanctions that define honorable behavior and implicitly condition regulators' goal function $\mathrm{U}\left(\mathbf{g}, \mathbf{g}^{\prime} ; \mathrm{S}_{\mathrm{T}}, \mathrm{S}_{\mathrm{R}}\right)$ and constrain regulatees' side-payment scheme $\mathrm{S}_{\mathrm{R}}\left[\mathrm{V}\left(\mathbf{g}^{\prime}\right)\right]$.

Taxpayer-principals understand the value of recruiting officials whose past behavior implies a goal function that incorporates a strong sense of honor. But they have not sought to use incentive contracting to align the incentives of watchdogs and public servants with societywide interests. An enforceable specification of regulatory duties and standards is an essential part of incentive reform. In a world of rapid technological change, this need not mean replacing regulatory discretion by a rigid policy rule. Ex post settling-up can align incentives as long as accountability attaches to discretionary decisions. But accountability cannot exist unless contracts are conditioned on observables. Observability requires the eventual --and, in most cases, the timely-- release and analysis of the relevant information policymakers reviewed when their decisions were made. In the past, authorities have too often been able to duck responsibility for the consequences of undersupervision because they could hide festering problems from the press. The problem is to elevate the level of post-mortem debates about the true benefits and costs of supervisory strategies and regulatory decisions by challenging regulators to defend in a candid fashion decisions they have made about monitoring, rulemaking, and enforcement.

Sectoral lobbying is facilitated when accountability for the exercise of governmental power is weak. Decisions that are bureaucratically and personally self-serving typically deliver hard-to-monitor noncash subsidies to regulatees in exchange for routing hard-todocument noncash favors and deferred job opportunities to pliable officials. Without strict 
disclosure requirements and truth-telling discipline, reasons for governmental actions and specific flows of sectoral benefits are easy to disguise. In every country in the world, regulators produce a flow of clever disinformation that makes it hard for taxpayers to monitor regulatory performance and police agency costs. The disinformational character of the typical policymaker press conference is summed up in a comment supposedly made to an inquiring reporter by a central-bank chairman. When the reporter claimed to "understand" the chairman's remarks, the chairman quipped, "Then I must surely have mis-spoken."

\section{Disciplinary Role of Regulatory Competition}

As with any other valuable service, regulatory benefits can be produced governmentally or privately and can be sited nearby or far away. The existence of alternative regulators that offer different reporting and disciplinary protocols clarifies that even governmental regulatory relationships are not entirely coerced. Local and multinational private credit-rating agencies and accounting firms compete with government bank examiners to produce reliable information about the condition of individual banks and banking systems. Local and multinational private clearinghouses compete with government-run payments networks around the world.

A private regulator must spend resources to accumulate police power that government entities receive costlessly. Also, because taxpayers and customers view a private regulator's motives skeptically, it has to bond itself to some degree against the likelihood that its or its employees' private interests will impair its regulatory performance. In contrast, government regulatory enterprises have less ability to bond their performance by transactions in capital and labor markets. Instead, the public is encouraged to believe that government managers are recruited from a class of extraordinarily honorable and altruistic citizens. Taxpayers are asked to hope against hope that members of this mandarin class respect the duties of loyalty, care, and competence they owe their taxpayer-principals and are strongly disciplined by the threat of public shame. This presumption of scrupulousness casts top officials as less easily tempted by incentive conflicts than a similarly situated private regulatory manager would be.

In the atomistic private-benefits theory, a regulatee's submission to a reliable supervisory and disciplinary authority is voluntary. It is accomplished through a web of implicit and explicit contracts drawn up jointly by regulators and regulatees. Because regulator-regulatee negotiations and contracts lack transparency, from a social-welfare point of view, regulatory discretion may be abused by seeking to impose costs on other parties that cannot quickly or costlessly defend themselves. Only if information flows freely and 
competition among regulators is strong, can abuses of regulatory discretion be reliably disciplined by private markets and the courts.

What competition among alternative suppliers of regulation does reliably limit is the burdensomeness of the contract a particular government regulator may successfully impose on its regulated-institution counterparties. The equivalent of a regulator's price is the difference between the costs and benefits that the regulator's disciplinary activities generate for its regulatees. This difference may be described as a regulator's net regulatory benefit (if positive) or burden (if negative), $\mathrm{NRB}=\mathrm{V}(\mathbf{g})-\sum_{i=1}^{m} u_{i}$.

Regulators that set their gross burden far above the market value of their coordination services lose clients, budgets, and prestige until they lower their burden appropriately. Most individual FSFs employ the services of several regulators. They unleash latent profit opportunities by shopping continually for opportunities to improve their own particular $\mathrm{NRB}_{\mathrm{i}}=\mathrm{V}_{1}\left(\mathrm{~g}^{\prime}\right)-\mathrm{u}_{\mathrm{i}}$. To the extent that switching costs allow, FSF managers look to migrate various business offerings to the lowest-price regulator.

When a government regulator can load substantial costs onto unwary taxpayers, it can set its NRB unsustainably low until taxpayers wise up. In this case, whatever interim regulatee migration occurs serves to reduce rather than to increase social welfare.

Changes in any regulator's rules or enforcement paradigm change the net regulatory benefits it promises its clients. At the margin, such changes induce FSF efforts to improve their NRB by consolidating or deconsolidating their pre-existing organizational "architecture." By architecture, we mean how an FSF locates and conducts different segments of its business operations. Arbitrage-like benefits are gained by strategically reconfiguring a regulated firm's operations to transfer them to less-burdensome jurisdictions. Using this perspective, regulation-induced consolidation or deconsolidation may be described as a "structural" process of regulatory arbitrage.

In the absence of switching costs, differences in the marginal net burdens of regulation set by different regulators for substitute contracts would be quickly erased by structural arbitrage and regulatory response. It is convenient to call this tendency toward long-run equalization, the Law of One Net Regulatory Burden.

It is important to recognize three conditions this law does not entail. First, because switching costs can sometimes be very high, equalization need not proceed rapidly. Second, equalization of net burdens permits gross burdens to differ across jurisdictions even in long-run equilibrium. To be sustainable, differences in gross burdens would have to reflect differences in market structure and in tastes for confidence and convenience across different regulators' populations of FSF clients and FSF customers. Third, as long 
as third-party costs can be credibly misrepresented, equalizing the net burdens of regulatees does not preclude the possibility that regulatory services are not produced at minimum cost nor that $\mathrm{u}_{\mathrm{i}}<\mathrm{c}_{\mathrm{i}}$ for at least some regulatees. In this case, discretionary exploitation of third parties occurs and may prove long-lasting.

\section{E. Patterns of Mixed Government-Private Regulatory Competition}

Agency theory emphasizes the motive force of good and bad incentives (Brennan, 1994). Financial regulation is a service that is supplied competitively, but exchanges take place in markets for political and bureaucratic services that are imperfectly contestable and potentially dysfunctional in the discipline they generate.

To apply the tools of industrial-organization theory to regulatory competition, it is convenient to view actual and potential financial regulators as individual firms. Each regulatory enterprise has an imperfectly observable mission statement of private and public goals. Contractual, statutory, political, and market restraints limit each regulator's ability to manipulate its instruments $\mathbf{x}$ to pursue its particular goals $\mathbf{g}^{1}$. These restraints evolve through time in response both to market forces and to sectoral lobbying activity. Unless it is unconcerned about its ability to shift costs or risks to taxpayers, it is unwise for a regulator to acknowledge openly its private goals or implicit costs.

Each regulator competes in a potentially global industry against other private and governmental entities for the right to produce benefits for FSF clients. Globally and locally, the markets in which suppliers of financial regulatory services compete are --using the framework for market-structure analysis established by Baumol, Panzar, and Willig (1986)-- "imperfectly contestable." For society, the degree of imperfection impairs the disciplinary force of regulatory competition.

Most existing regulators possess a notable measure of monopoly power over their existing client base. They earn quasi-rents from informational and reputational advantages conferred by their past regulatory activity. These rents are further protected by client and competing-regulator switching costs. Regulators must incur substantial costs to enter new arenas and can absorb substantial losses before they voluntarily exit an old arena. On the other side of the market, would-be client structural arbitrageurs face substantial costs for searching out a less burdensome regulator and for adapting their charter or product line to switch into new jurisdictions.

The distribution of financial-institution revenues between public and private benefits and across competing regulators moves with regulatory arbitrage. Changes in market structure for the governmental tier of the global regulatory industry typically trail rather than lead changes in the market structure of more competitive arenas for private regulation and financial services. 
A private regulator (such as an exchange or clearinghouse) may exogenously changes its rules or enforcement procedures to adapt to a new contracting or information technology. More frequently, an FSF that is supervised by a particular regulator adapts its line of business to take longstanding profit opportunities and market share away from a differently chartered and differently regulated category of FSF. Although government regulators of firms that lose cumulative market share react defensively to losses in their share of regulatory revenues, they tend to do so only after a substantial lag.

Until the 1970s, familiar categories of FSFs (banks, thrifts, insurance companies, sales-finance companies, and securities firms) could be reliably defined by a longstanding specialization in one or two "signature" financial contracts. But advances in computer, communications, and financial-contracting technology have created substitutes for these signature contracts and destroyed the usefulness of contract-based lines of demarcation. Technological change is increasing the ability of differently chartered U.S. FSFs and of similarly-chartered firms located in foreign countries to invade nontraditional markets by offering effective substitutes for once-exclusive financial-contract forms. Whether designed to attract savings or to channel savings to would-be deficit spenders, previously unique contracts face a growing number of close substitutes.

Country by country during the last 30 years, technological change has made markets for substitute financial contracts and regulatory services more closely contestable. Cumulative entry by foreign FSFs and the genericization of restrictively chartered domestic FSFs have brought once-independent regulatory enterprises into close competition. The resulting redistribution of financial market shares spreads efficient regulatory technology, improves information flows, and reshapes the domestic and global market structure of financial regulation. This increased competition among FSFs has reduced costs of exit, entry, and information acquisition in regulatory markets, but information flows and competition among regulators remain imperfect. The opportunity costs of government regulation typically still exceed user changes. Better information and better contracting protocols are needed before taxpayers can entrust the task of disciplining government regulatory officials entirely to the vagaries of markets for regulators and regulatory services.

\section{Regulating Government Regulators: Aligning Public and Private Regulatory Incentives}

Financial regulation consists of efforts to monitor, discipline, and coordinate the behavior of individual firms in the financial-services industry to promote specific purposes. These purposes include the wholly salutary microeconomic goals of increasing customer confidence and convenience in FSF products. Regulators must be held 
accountable for the tradeoffs they make between these industry-specific goals and their macroeconomic counterparts (financial stability and resource efficiency).

It is axiomatic that a system of rewards and punishments is required to incent an agent to pursue a principal's goals. Common law assigns elected politicians a poorly enforced ethical duty to monitor and minimize the opportunity cost of producing regulatory services in government agencies. As agents both for taxpayers and for FSFs, officials should be accountable for establishing that, for each regulatee, user charges $u_{i}$ equal $c_{i}$ the opportunity costs of producing industry-specific regulatory benefits. It violates officials' duty to taxpayers if they finance reductions in net regulatory burdens for multinational and multipurpose financial firms by backdoor "deals" that shift hidden costs onto uninformed taxpayers.

Management contracts for government officials seldom include the positive incentive of compensation that rises and falls with success in achieving taxpayer goals. At the same time, disincentives that compromise taxpayer goals come from a regulated industry's ability to offer laundered bribes and to penalize top regulators by unfairly undermining their reputations with disinformational criticism and praise. Trade-association officials loudly boo proactive interventions that promise to lessen taxpayer loss exposures and enthusiastically applaud delaying tactics that have the opposite effect. Unless watchdog institutions in the press and academia are informed and engaged enough to issue a contrary flow of better-directed applause and catcalls, top regulators have an incentive to temporize.

Accountability for regulatory mistakes requires making official actions and their consequences more transparent and imposing timely penalties on incompetent and corrupt behavior. When taxpayers shun incentive contracts for financial regulators, agency theory predicts that five time-wasting disinformational propensities would be routinely exhibited by politicians and top bureaucrats. These dysfunctional propensities flow from the perverse incentives created by inadequate accountability for poor performance in government office. The five propensities are:

1. A propensity for top officials to keep themselves underinformed about threatening financial crises or scandals. We may call this the blindfold or ostrich reflex. The value of this propensity is that it creates deniability options that help to deflect blame once a longstanding problem transforms itself into a public scandal.

2. A propensity to use the weight of their high office as a weapon with which to denigrate critics in watchdog institutions and to calm the public even in the 
absence of reliable information. We may call this the denial or trust-me reflex.

3. A propensity to conceal past mistakes and to discredit critics in watchdog institutions by twisting facts and covering up unfavorable information. We may call this the cover-up reflex.

4. A propensity to misdirect public attention toward trivial issues or toward problems that lie in someone else's bailiwick. We may call this the distraction reflex.

5. A propensity to assign blame for errors rightly or (more frequently) wrongly to convenient, credible scapegoats. As a secondary form of cover-up, selecting someone to take the fall for others is a weaselling effort to rewrite history. We may call this the guilt-shifting reflex.

The U.S. deposit-insurance mess exemplifies the difference between the private and social costs of governmental disinformation. It is instinctive for politicians and regulators to claim to have been blindsided by the expanding costs of deposit-institution insolvency when and if insolvency surfaces. But in the U.S., top officials' inability to see accruing losses was willful to an important degree. Government officials ignored longstanding academic warnings about distortions in deposit-institution risk-taking incentives (Emerson, 1934; Scott and Mayer, 1971; Kareken, 1983) and refused to heed persuasive empirical evidence concerning the increasingly massive size of unbooked opportunity losses.

At the very least, officials' repeated refusal to face unpleasant facts indicates an insensitivity to the duty of care they owe to taxpayers. This duty should oblige regulators to analyze and clarify the long-run consequences of the monitoring and other loss-control policies they adopt. In choosing not to measure and reserve for appraisable losses that were plainly developing on an opportunity-cost basis in decapitalized clients, U.S. regulators dishonored their obligation to taxpayers. Their inadequate information system reinforced the lobbying pressure that the deposit-institution industry could exert against efforts to install a more-effective premium structure and supervisory framework. Underreporting their funds' loss exposures meant that, before regulators were obliged to bring troubled institutions under public control, opportunities to delay the recording of industry losses in official accounting records could play themselves out.

Although the mess ripened slowly over 25 years, U.S. regulators and watchdog institutions did little to warn their taxpayer-principals about the accumulating cost of resolving S\&L insolvencies. Nor are their successors alerting the public today to informational deficiencies that have been carried over into the new and improved regulatory system installed during 1989-1991 (Kane, 1995). 
The FDIC Improvement Act of 1994 (FDICIA) increased penalties and tightened enforcement for fraud and violations of faith by private managers of insured deposit institutions. Incentives for honest and faithful government regulation of these same institutions were not improved to the same degree. Congress contented itself with spelling out more fully two supervisory duties of federal regulators: duties of prompt corrective action and least-cost insolvency resolution. But accountability for regulator's supporting duties of vision and truth-telling was not enhanced. Recent legislation has done nothing to improve the legal enforceability of penalties officials nominally face for ignoring material information on FSF weakness or for concealing losses from taxpayers in violation of their common-law duties of loyalty, competence, or care (Kane, 1996).

It is disingenuous to attribute deposit insurance losses to technical ignorance about how to measure and bond either deposit-institution or regulatory performance. Agency theory roots taxpayer loss exposures in unresolved conflicts of interest between government officials and taxpayers. This incentive conflict introduces dishonorable tradeoffs that undermine regulatory performance. Society's problem with deposit insurance is a contractual one: to establish incentives that prevent the selective and repeated nonenforcement of key provisions in the deposit-insurance contract from benefiting responsible officials.

The work of even the most conscientious regulators and politicians involves cutting deals with interested parties. Successful deals accommodate the desires of the various bargainers and negotiate a middleground position with which all parties can live. The weakness in the risk-based capital framework of regulation ratified by the $\mathrm{G}-10$ countries in 1988 is that the deal surreptitiously shortchanges taxpayers. It does this by preserving opportunities for regulators to allow troubled and aggressive institutions to use accounting leeway to mislead regulators and the public alike about the size of an institution's net risk exposures and unbooked losses. Accepting misinformation from regulated institutions expands opportunities for regulators to overstate the quality of their supervisory performance and for politicians to mediate perversely between bankers and regulators. While seeming to dictate prompt discipline for failing banks, the risk-based capital standards preserve officials' discretion to misdesign their accounting tripwires and to frame inadequate responses to palpable unbooked evidence of emerging problems.

Tools for Better Aligning Regulator Incentives

It is possible to attenuate antisocial private benefits from disinformational government activity in several ways. Most simply, employment contracts could assign top regulators a specified share of whatever gains and losses their policies impose on taxpayers. Even if the upside of taxpayer gains were not shared, it would rebalance 
incentives if some of the losses experienced in making good on a government's implicit and explicit deposit guarantees were "owned" by parties who dictate the system's loss-control policies (Phaup, 1992). One can envision raising the base pay or pension claims of responsible officials sufficiently to cover the human-capital risk of accepting this losssharing responsibility. Phaup suggests assigning the first several million dollars of any unreserved deposit-insurance loss pro rata to the corporate managers of the particular government enterprise that was responsible for supervising the loss-causing institution. This liability could be enforced by making it senior to each responsible official's claim to payments from his or her government pension fund (see, e.g., Wall, 1996). Such contracts would further improve incentives by making it easier in the future to bring civil suits against regulators who support policies that may be expected to increase the costs of supporting the financial safety net: choosing not to reserve for distant but readily appraisable losses; using smoke-and-mirrors accounting to cover up inadequacies in bureaucratic performance; and sacrificing broad taxpayer interests in response to sectoral political pressure.

More generally, the process of aligning regulatory incentives with the interests of taxpayers has two steps. The first step is to improve the monitoring incentives and capability of news organizations and academic researchers. The intellectual level of public debate about financial supervision and regulation in the U.S. is embarrassingly low. Coverups occur de facto whenever the long-run budgetary implications of capitalsupervision decisions are not adequately measured and discussed at the time they are being made. Taxpayer loss exposure cannot be accurately reserved for by covering losses in projected near-term bank "failures" a year or two ahead on a pay-as-you-go basis. The second step is to require officials to cost out in reproducible fashion what taxpayers would have to pay a well-managed private entity to take the government's net future exposure to losses in bank insolvencies off taxpayer hands.

Budgetary information systems are not now designed to alert people outside the government when regulators and politicians are depriving taxpayers of a fair return on the reputational capital they supply to a government regulator. Until taxpayer loss exposures from deposit-institution risk taking are accurately reported as they accrue, in times of financial stress incentive conflicts will tempt politicians and regulators to compound taxpayer damage by relaxing solvency standards and otherwise delaying accounting recognition of increases in taxpayer support for troubled institutions. It is foolish to suppose that opaque strategies for refinancing deposit-institution losses, policies of imprudently lenient supervision, and procedures for hiding the nationalization of troubled institutions and assets developed by accident. 
A direct path for unblocking the information flow is to impose comprehensive market-value accounting principles and self-reporting obligations on regulators and insured institutions alike. The goal is to create strong incentives for these enterprises to measure their intertwined performance and accumulating loss exposures as accurately as they can. But, as in winning compliance for tax laws, the trick is to put incentive weight behind reporting obligations. This means building political support for subjecting obliged parties to effective monitoring and enforcement. Parallel civil and criminal penalties and enforcement procedures for managers who willfully publicize less than their best estimate of their enterprise's market value should apply to private and government officials alike.

Penalizing disinformational reporting would make it easier to identify and penalize poor regulatory performance. Shortfalls in regulatory performance can only be defined relative to an explicit standard of regulatory duty. In the U.S., the FDIC Improvement Act of 1991 (FDICIA) erects performance standards that require regulators to eliminate or resolve deficiencies in risk-adjusted accounting measures of individual-bank capital. These capital standards represent a useful start, but a better-calibrated basis for conditioning supervisory action exists. The ideal goal would be to identify and control the opportunity cost of the loss exposure each institution passes through to the applicable insurance fund. The improved information system envisaged here would make it feasible for taxpayers to require regulators to document and directly control the net regulatory benefits flowing to each bank.

Discretion over the timing of recognizing losses and institutional insolvency would be lessened in an opportunity-cost reporting system. This would leave supervisory standards for recapitalization and closure less open to abuse than they are under FDICIA. Backed up by appropriate penalties, the following ethical requirements would enhance regulatory accountability for measuring, pricing, and managing the value of implicit and explicit government guarantees:

a. To require government officials to eliminate net taxpayer loss exposures in insolvent deposit institutions quickly, i.e., according to a strict timetable;

b. To require costs of resolving taxpayer loss exposures to be reserved for and funded in the federal budget as they accrue;

c. To require incumbent politicians:

1) to set explicit limits on their ability to intervene without penalty into the process of closing or recapitalizing individual institutions;

2) to report all interventions to legislative committees and judicial bodies for explicit review; 
3) to submit information uncovered in committee and judicial reviews to outside evaluation by special prosecutors and watchdog institutions.

\section{Benefits from Partial Privatizing Deposit-Insurance Loss Exposures}

Improved accountability for government regulators requires that watchdog institutions be willing and able to monitor regulatory performance. Authorities have an incentive to resist increases in accountability. Conflicted officials directly control the agenda of reform.

Difficulties in implementing tough reforms in the incentive system governing bank regulation enacted in FDICIA illustrate the reputational and other benefits that regulatory reform must address. FDICIA makes monitoring deposit-institution risk exposures and ownership stakes the central line of taxpayer defense. But top federal banking regulators continue to resist accounting reforms that would make them more accountable for catching institutions whose capital cannot support the full range of risks to which it is exposed. Delays in incorporating interest-rate risk exposure into risk-based capital requirements seem unconscionable when it is clear that the $\$ 180$ billion it cost taxpayers to clean up the S\&L insurance mess (Ely and Varaiya, 1996) originated in interest-rate risk taking by S\&Ls.

Although FDICIA asks regulators to measure deposit-insurance loss exposures created by leveraged funding imbalances, it enacts no mechanism for enforcing this duty. By asserting a counterduty to keep the measurement system simple and the reporting effort imposed on insured institutions light, U.S. banking regulators have kept subsidies to aggressive institutions from registering on the government's books.

Resistance to information-system reform could be lessened by privatizing depositinsurance loss exposures in ways that would enhance the accountability of government supervisors. Privatization entails "any loosening of government controls, including the sale of minority interest in a state-owned enterprise to private buyers, the delegation of management responsibility for a state-owned enterprise to private managers, and even the relaxation of a state monopoly to allow private entry into the market" (Vernon, 1988, p. 2). Regulators' core task is to protect the insurance fund by identifying problem institutions and correcting or resolving their problems before accumulating losses exceed an institution's capital and thereby impose a charge against deposit-insurance reserves. Loss control entails timely risk measurement, appropriate risk management, and prompt insolvency resolution. Banking regulators' stubborn reluctance to collect the information they need to control interest-rate risk stands as a powerful argument for privatizing bankexamination and loss-control functions. 
The simplest approach is to assign the first layer of deposit-insurance losses to private parties that are empowered to enforce proactive loss-control decisions. Requiring that private parties underwrite the first layers of the insurable risks in deposit insurance system would create a partnership of tiered private and government guarantees. Whether effected through expanded use of noncollateralizable subordinated debt or through private coinsurance, the loss-control interests of the private partners would tighten monitoring procedures, rationalize credit-enhancement fees, and improve the structure of disciplinary enforcement. To cope with technological change, the private partners would also have to take over responsibility for deciding under what circumstances insured institutions may safely enter nontraditional activities. In contrast to existing arrangements, the privatized entry barriers should only slow cross-market entry into product lines whose profitability comes from shifting loss exposures to taxpayers.

With partial privatization, the loss exposure the taxpayer faces in deposit institutions would be shared explicitly with one or more private guarantor. This partial privatization of loss control and deposit-insurance responsibilities would create information flows in private capital markets that would make it easier for taxpayers to monitor their stake in federal deposit insurance. Like canaries carried into a coal mine, adverse movements in the market prices of equity and debt instruments issued by the government's private partners would signal the press and academia that parallel problems existing in the government's complementary system for supervising and controlling the loss exposures undertaken by its private partners. The difficulty of dismissing these market signals would pressure government officials to make better decisions.

\section{Accountability and Accounting Transparency}

Outside monitoring is difficult when generally accepted accounting principles fail to develop information about opportunity costs. At depository and insurance firms today, principles of historical-cost valuation and of excluding most intangible values from itemization make accounting records unreliable guides both to risk-taking patterns and to the true values of an insured institution's economic income and net worth. Historical-cost tangible accounting helps to make financial institutions that employ it and government insurance funds that back them into "informationally opaque" entities.

To identify and measure changes in risk exposure in timely fashion, regulators must be empowered to inspect institutional books in forward-looking and ever-changing ways. This is as true of insurance companies and deposit institutions as it is of pension plans and securities firms. To manage efficiently the risk exposures their inspections identify, regulators must possess the expertise and contractual power to observe and discipline at reasonable social cost whatever risk taking seems inappropriate. While government 
enterprises possess these capacities, their managers have repeatedly shown a lack of will to use them. In particular, when many institutions come under stress at the same time, incentive conflicts tempt government officials to waive important elements of their losscontrol authority.

Proposing to shift the initial layer of financial-institution losses to the private sector presupposes that private parties can reliably monitor and discipline relevant forms of institutional risk taking. As compared to uninsured depositors, subordinated debtholders and specialized private bonding companies loom as potentially efficient candidates for this task. Both types of institutions use contracting protocols that expressly accept the risks that their counterparty's net worth will become exhausted in exchange for collecting an ex ante monitoring and risk-bearing premium. Having volunteered to bear losses from mistakes they themselves make in monitoring and controlling their counterparty's risk taking leaves these parties poorly positioned politically to force the government to bail them out.

Controlling incentive conflict in financial regulation begins with reducing opportunities for covering up financial-institution weakness. To rationalize the exit or consolidation of unsuccessful deposit institutions and to assure a reasonable return from activities of asset salvage, it is necessary to enhance market surveillance of monitoring, loss-control, and loss-reserving activities. A straightforward way to do this is for the government to cede to private bonding companies or to agents directly responsible to subordinated debtholders most of the supervision and examination functions that in most countries are now performed by government employees.

The metaphor for accounting transparency is an untinted shop window, through which customers can see what goes on inside a retail store. To the extent that a trained financial analyst cannot truly and fairly assess an institution's risk-taking and profitability by looking through its accounting records, the institution's information system is said to be "opaque."

This paper stresses that the risks to taxpayers from poor regulatory performance come not just from lack of transparency in the accounts of regulated financial institutions, but even more importantly from nontransparencies and disinformation in the accounts that government regulators are permitted to transmit to their taxpayer-employers. Fair and efficient bank regulation cannot be sustained unless and until a society forges a chain of incentive-compatible contracts across the series of linked principal-agent relationships encompassed in the solid lines in Figure Two. Incentives to engage in taxpayer-exploiting behavior are represented by the dotted lines of the Figure. Incentive-based contracts for public servants are needed to shrink the antisocial value of the interaction captured in the dotted lines. 
The problem is not just to improve the transparency of the accounts that private financial institutions keep: e.g., by replacing par-value deposit liabilities with Islamic-banklike mutual-fund shares as Franklin Edwards (1995) has proposed. The social efficiency of the contracts written between customers and institutions depends most importantly on the efficiency of the incentives generated by the employment contracts under which public servants work. Contracts for public officials cannot be efficient unless these contracts minimize the net private benefits a regulator can accrue from responding to sectoral lobbying and covering up the extent to which adjustments in regulatory instruments lower user fees $u_{i}$ or increase private value $V$ at the expenses of societal benefits $B$. As long as helping troubled firms at taxpayer expense offers regulatory officials a net expected return, society will find it hard to erect patterns of fair and efficient regulation.

Every new episode of weakening financial markets is accompanied by a reflex plea for regulatory assistance from the currently troubled class of firms. It is all too easy for government officials to authorize --and for lower-level employees to tolerate-nontransparent forms of creative "accounting relief" for which taxpayers are not compensated by user charges.

Accounting relief undermines the enforceability of the loss assignments that the owners and customers of insured financial institutions accepted ex ante. Unlike government officials, private regulatory managers know that if poor management of financial-institution loss exposures engulfs subordinated debtholders or causes a private bonding company to deplete its fund of gross reserves, punitive market forces will threaten their jobs. As a byproduct of regulatory privatization, those same market forces would generate timely and transparent market signals that things must be going badly for taxpayers too.

Private investors anticipate earning profits from developing and acting upon information about impending changes in the value of any tradable claims. Profit opportunities would incent analysts to monitor impending changes in the value of an institution's subordinated debt (see Benston, et al., 1986; Wall, 1989) or in the credibility of a bonding company's guarantees. However, I submit that for taxpayers the signalling value of a bonding company's weakness is easier to grasp than a decline in the value of a deposit institution's subordinated debt. To untangle information events in subordinateddebt markets, taxpayers and the press would have to undertake sophisticated analyses of collateral adjustments, analyses whose very sophistication would allow high government officials more credibly to dispute their meaning.

Declines in a private bonding company's credibility create widespread private loss exposures that a responsible press cannot help but notice. This notice is bound to decrease 
the demand for the bonding company's services and to increase the regulatory scrutiny the company must face. At the same time, falling demand would reduce the bonding company's current and projected earnings. Although the effects would be attenuated by whatever implicit safety-net support the market expects to flow to these firms, a poorer profit outlook is bound to depress the market value of the company's stock and the worth of its outstanding guarantees to depositors. Such developments create pressure for stockholders and creditors to press the firm's management to adopt improved loss-control strategies and for outside firms to identify the company as an attractive takeover target.

This unfolding market information would unambiguously signal taxpayers, academic researchers, and news organizations that some of the private bonding company's growing loss exposure had passed through to its government partner. Such clear signals would turn the week-to-week travails of the partner company into "drumbeats of news" about taxpayers' changing loss exposure. In this way, instead of being the unobservable "nonevents" they were during the burgeoning U.S. deposit-insurance mess, government leniency and its consequences would feed a stream of recognizable news events. These events would have easy-to-explain political implications about sectoral conflict that mainstream news media would gladly expose (Skidmore, 1992). Generating better information is the first step toward subjecting the reputations and career prospects of government managers to timely market discipline. 


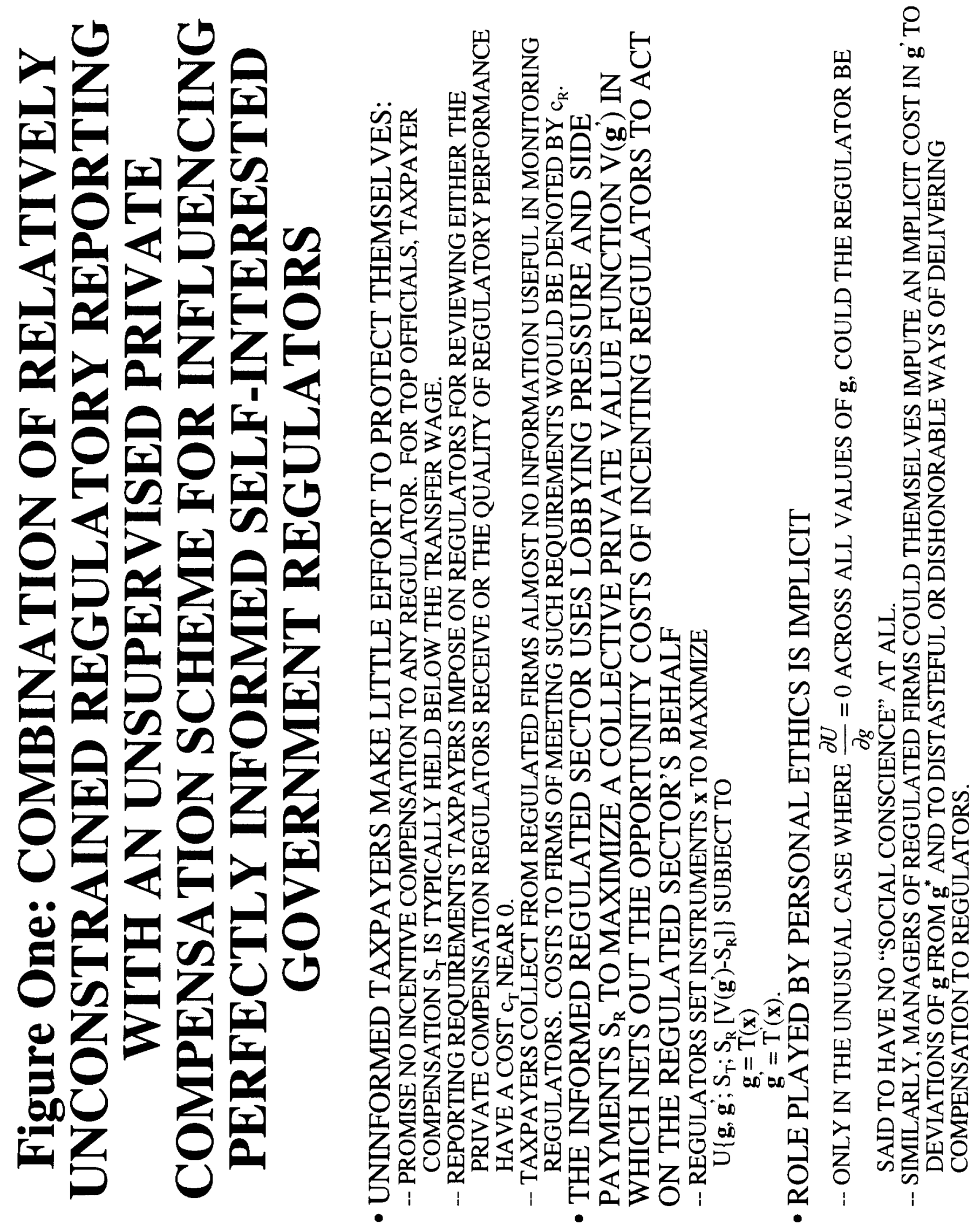




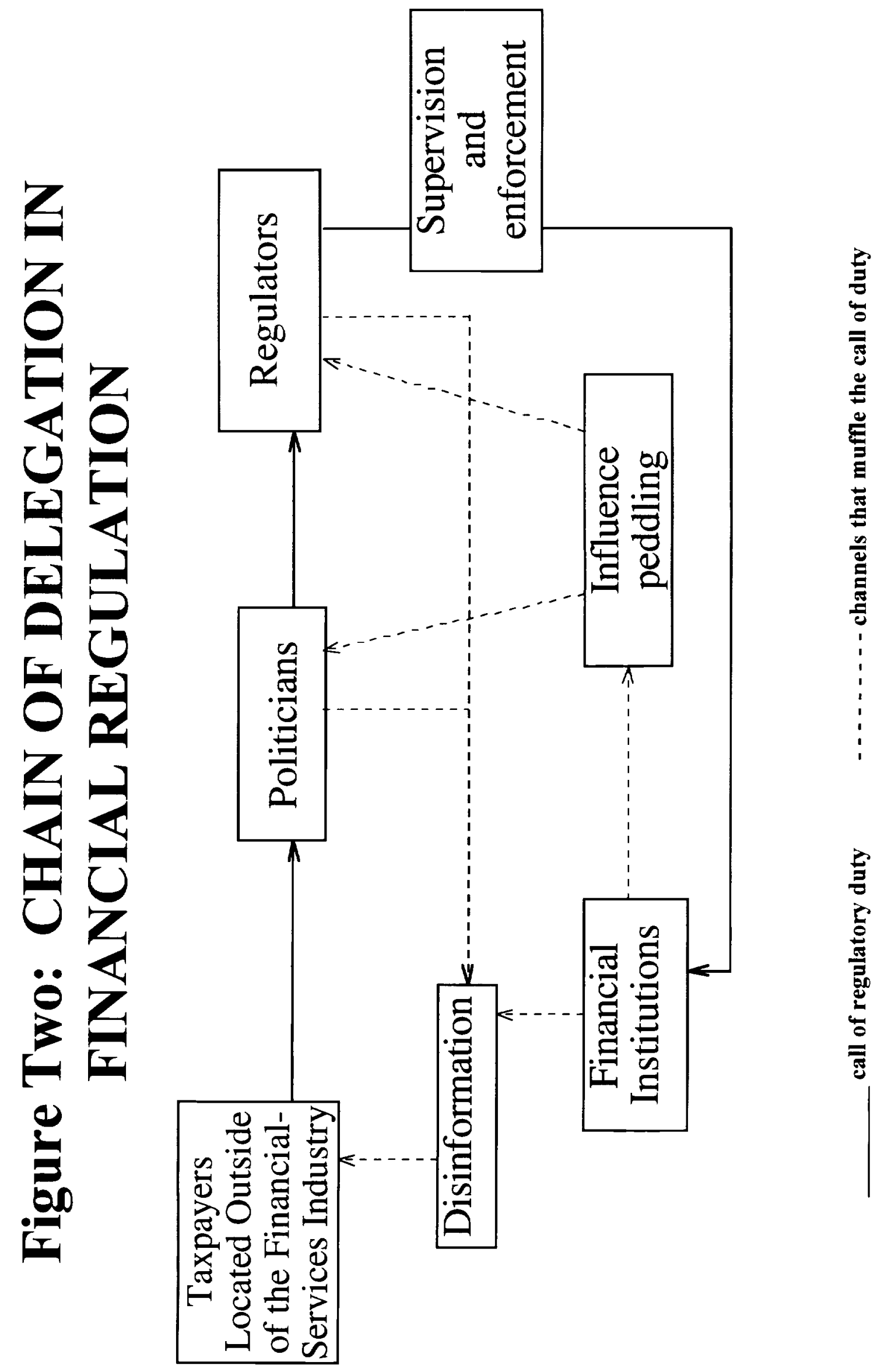




\section{REFERENCES}

Baumol, William J., John C. Panzar, and Robert D. Willig, 1986. "On the Theory of Contestable Markets," in New Developments in the Theory of Industrial Structure, edited by G.F. Matthavson and Joseph Stiglitz. Cambridge, Mass.: MIT Press.

Becker, Gary S., 1983. "A Theory of Competition Among Pressure Groups for Political Influence," Quarterly Journal of Economics, 98(August), pp. 371-400.

Benston, George, Robert Eisenbeis, Paul Horvitz, Edward Kane, and George Kaufman, 1986. Perspectives on Safe \& Sound Banking: Past, Present, and Future, Cambridge, Mass.: American Bankers Association and MIT Press.

Benston, George, and George Kaufman, 1996. "The Appropriate Role of Bank Regulation,” The Economic Journal, 106(May), pp. 688-697.

Brennan, Michael J., 1994. "Incentives, Rationality, and Society," Journal of Applied Corporate Finance, 7(Summer), pp. 31-39.

Bruun, Madalene C., 1994. “A Specific Framework for Ethical Decision Making: Whistleblower Protection," Paper Presented at the Annual Meetings of the Eastern Economics Association, Boston, MA.

Calomiris, Charles W. and Joseph R. Mason, 1994. "Contagion and Bank Failures During the Great Depression: The June 1932 Chicago Banking Panic," Cambridge, Mass.: NBER Working Paper \#4934.

Coase, Ronald H., 1960. "The Problem of Social Cost," Journal of Law and Economics, 3(October), pp. 1- 44.

Diamond, Douglas, 1984. "Financial Intermediation and Delegated Monitoring," Review of Economic Studies, 51(July), pp. 393-414.

Edwards, Franklin, 1995. "Financial Regulation for the 21st Century: Proposals for Reforming Bank Regulation," unpublished paper prepared for Koç University Symposium on Public Regulation of Depository Institutions, Istanbul, Turkey.

Ely, David, and Nikhil Varaiya, 1996. "Opportunity Costs of Cleaning up S\&L Insolvencies," Quarterly Review of Economics and Finance, 36(Fall), pp. 291310 .

Emerson, Guy, 1934. "Guaranty of Deposits under the Banking Act of 1933," Quarterly Journal of Economics, 48(February), pp. 229-244.

Fama, Eugene, and Michael Jensen, 1983. "Separation of Ownership and Control," Journal of Law and Economics, 26, pp. 301-325. 
Jensen, Michael C., 1994. "Self-Interest, Altruism, Incentives, and Agency Theory," Journal of Applied Corporate Finance, 7(Summer), pp. 40-45.

Jensen, Michael C., and William Meckling, 1975. "Theory of the Firm: Managerial Behavior, Agency Costs, and Ownership Structure," Journal of Financial Economics, 3(June), pp. 305-360.

Kahneman, Daniel, Jack L. Knetsch, and Richard Thaler, 1986. "Fairness As a Constraint on Profit Seeking: Entitlements in the Market," American Economic Review, 76(September), pp. 728-741.

Kane, Edward J., 1988. "How Market Forces Influence the Structure of Financial Regulation." In Restructuring Banking and Financial Services in America, edited by William Haraf and Rose Marie Kushmeider, Washington: American Enterprise Institute, pp. 343-382. , 1995. "Three Paradigms for the Role of Capitalization Requirements in Insured Financial Institutions," Journal of Banking and Finance, 19(June), pp. 431-459. , 1996. "Contracting for Improved Supervisory Performance from Federal Banking Regulators," Paper prepared for Brookings Institution Conference on FDICIA: Bank Reform Five Years Later and Five Years Ahead (unpublished).

Kareken, John H., 1983. "Deposit Insurance Reform; or Deregulation Is the Cart, Not the Horse," Federal Reserve Bank of Minneapolis Quarterly Review, 7(Spring), pp. 1-9. Pelzman, Sam, 1976. "Towards a More General Theory of Regulation," Journal of Law and Economics, 19(April), pp. 211-240.

Phaup, Marvin, 1992. "Long-Run Benefits in Financial Regulation," in Peter Dickson (ed.), Rebuilding Public Confidence through Financial Reform, Columbus: Ohio State University School of Business, pp. 78-79.

Pigou, A.C., 1932. The Economics of Welfare. Fourth Edition. New York: Macmillan. Samuelson, Paul A., 1947. Foundations of Economic Analysis. Cambridge, Mass.: Harvard University Press.

Scott, Kenneth E., and Thomas Mayer, 1971. "Risk and Regulation in Banking: Some Proposals for Federal Deposit Insurance Reform," Stanford Law Review, 23(May), pp. 857-902.

Skidmore, Dave, 1992. "Information Economics and the Press," in Peter Dickson (ed.), Rebuilding Public Confidence through Financial Reform, Columbus: Ohio State University School of Business, pp. 100-101. 
Stigler, George, 1971. "The Theory of Economic Regulation," Bell Journal of Economics, 1(Spring), pp. 3-21.

Vernon, Raymond, 1988. The Promise of Privatization: A Challenge for American Foreign Policy. New York: Council of Foreign Relations, Inc.

Wall, Larry, 1989. “A Plan for Reducing Future Deposit Insurance Losses: Puttable Subordinated Debt," Economic Review, Federal Reserve Bank of Atlanta (July/August), pp. 2-17.

, 1996. "Bonding the Regulators: A Plan for the FDIC to Issue Capital Bonds," Federal Reserve Bank of Atlanta (unpublished, December). 